\title{
Design and Implementation of Non-Invasive Telemedicine System for Detecting Cholesterol Levels in Blood as a Solution during the Covid-19 Pandemic
}

\author{
Tria Nurmar'atin ${ }^{1, *}$ Heni Sumarti ${ }^{1}$ Muhammad Ardhi Khalif ${ }^{1}$ \\ ${ }^{1}$ Department of Physics, Faculty of Sains and Technology, Universitas Islam Negeri Walisongo Semarang, Indonesia \\ *Corresponding author. Email: trianurmaratin_1708026029@student.walisongo.ac.id
}

\begin{abstract}
Excess total blood cholesterol can cause heart vessel disorders, stroke and the most fatal can cause death. Checking cholesterol levels should be done regularly, especially for someone who has reached adulthood. The implementation of a telemedicine system by utilizing digital technology provides convenience in exchanging medical information for early monitoring, diagnosis, and disease prevention during the Covid-19 pandemic. The design of this system can help reduce medical waste that is increasing during the pandemic. Cholesterol levels are detected using the Oxymeter sensor DS$100 \mathrm{~A}$ which is placed on the finger by utilizing the absorption of infrared wavelengths. Arduino Uno R3 microcontroller as a minimum system for controlling the output value in the form of digital data. The measurement results are displayed on a 20x4 liquid crystal display (LCD) and an android smartphone based on the Blynk application with communication via the internet using the Wifi NodeMCU 8266 module. Testing of the instrument was carried out by measuring cholesterol levels in 35 samples taken randomly, then compared using invasive and non-invasive methods. The results of testing the tool obtained an average error value of $17.24 \%$ with a tool accuracy value of $82.76 \%$. The final result of the error rate analysis shows that this cholesterol level detection system can be used as a rough estimate only because it is less than the limit of accuracy of medical devices that can be used for humans, which is more than or equal to $95 \%$. The telemedicine system can display data on the Blynk application screen with an average transfer time of $2.36 \mathrm{~s}$.
\end{abstract}

Keywords: Cholesterol, Non-Invasive, Oxymter sensor DS-100A, Telemedicine.

\section{INTRODUCTION}

Since the 20th century, pulmonary tuberculosis, which previously became an epidemic disease in developed countries, has been replaced by heart and blood vessel disease. Based on estimates from the World Health Organization (WHO) there are about $50 \%$ of the world's population die from heart disease and blood vessel blockage or stroke every year [1]. World Health Statistics 2008 has recorded that 17.1 million people died from coronary heart disease and the estimate will continue to increase to 23.4 million deaths in the world by 2030 [2]. One of the main causes that trigger the disease is the high levels of cholesterol in the blood [1]. Therefore, it is very important to check cholesterol levels in the blood regularly, especially for someone who is starting to reach adulthood because basically physical activity and body mass will decrease as age increases, while fat tissue will increase [3], [4]. Cholesterol levels are said to be normal when the value is less than 200 $\mathrm{mg} / \mathrm{dl}$ and quite high when in the range of $200-239 \mathrm{mg} / \mathrm{dl}$, while cholesterol levels are said to be high if the value is more than $240 \mathrm{mg} / \mathrm{dl}$ [5].

Checking cholesterol levels is generally done noninvasively or pricking a finger with tweezers to take a blood sample. Then the sample will be placed on a strip and inserted into the meter tool to determine blood cholesterol levels[6]. Invasive techniques are considered less effective because they can cause a risk of infection when in direct contact with tissue [7]. In addition, the cost of checking is quite expensive and requires a long time for laboratory analysis [8].

The latest technology introduces non-invasive techniques as an alternative approach to measuring cholesterol levels in the blood for diagnosing diseases without injuring the patient's body [9]. One technology that makes it possible to detect cholesterol levels in the blood non-invasively is by utilizing the absorption properties of light/laser on liquid media [8]. 
Sourced from previous research, namely an examination to measure cholesterol levels in the blood non-invasively or without injuring the patient's body by utilizing the Nellcor sensor produces an accuracy of $82.28 \%$ with a detection time of 30 seconds [8]. Measurements of cholesterol levels by utilizing the absorption properties of light or lasers have been widely carried out, one of which is a tool designed to measure cholesterol levels using an oximeter sensor and an accuracy of up to $97 \%$ is obtained, but based on the overall test results, the sensor voltage output with the real measured cholesterol value is still not constant [1]. Another study uses a sensor strip (autocheck) to measure cholesterol levels invasively with an accuracy rate of $94.65 \%$, the data can be displayed on the LCD (Liquid Crystal Display) and web server [10].

The principle of the pulse oximeter is based on optical plethysmography and blood oximetry, to calculate oxygen saturation through the amount of light transmitted or reflected in the blood vessels, then synchronized using the heart rate [11]. The name pulse oximetry is taken from the waveform formed by light which is modulated by arterial pulses [12]. The oxymeter sensor uses light to measure oxygen saturation, that is, the detection and quantification of the component (hemoglobin) in solution [13]. This process occurs by connecting a transducer containing a light emitter and photodetector to a highly perfused area such as a finger, toe, or earlobe. The light is transmitted, then detected by a photodetector and converted into a voltage signal called a photoplethysmogram (PPG) [14]. The optical sensor consists of two light sources as well as a detector. $\operatorname{Red}(660 \mathrm{~nm})$ and infrared(IR) $(880-940 \mathrm{~nm})$ are the wavelengths commonly used to calculate $\mathrm{SpO}_{2}$ [15]. A new algorithm was developed to calculate cholesterol levels, derived from the generated PPG signal. The light reflected from the sensor is passed through the signal processing module to be processed and processed by the microcontroller, then converted into digital data by the Analog Digital Converter (ADC) [16], in this case it is Arduino Uno [17].

Based on the background of the problem that has been described, we are trying to create and realize a noninvasive blood cholesterol level measurement device without sterilizing fingers and injuring one of the body's limbs using the Oxymeter Sensor DS-100A based on the Blynk application. The prototype tool can read cholesterol data in real time and has a faster time in detecting cholesterol levels compared to using an invasive measuring instrument which usually takes 25 seconds. Therefore, this research is expected to facilitate the measurement and monitoring of cholesterol levels in the blood in real-time and more efficiently.

\section{METHODS}

This research includes development research or commonly known as Research and Development (R\&D) which produces a product, then tests the product [18]. The population and samples in this study consisted of 10 random samples for calibration and 35 samples for instrument testing which were taken randomly in the age range of 20-60 years, both male and female with normal cholesterol levels and high cholesterol levels. Figure 1 shows the research flow starting from the design of tools, both hardware and software. The hardware design consists of making non-invasive measuring instruments, while the software design consists of programming a series of sensors and microcontrollers as well as the NodeMCU 8266 wifi module.

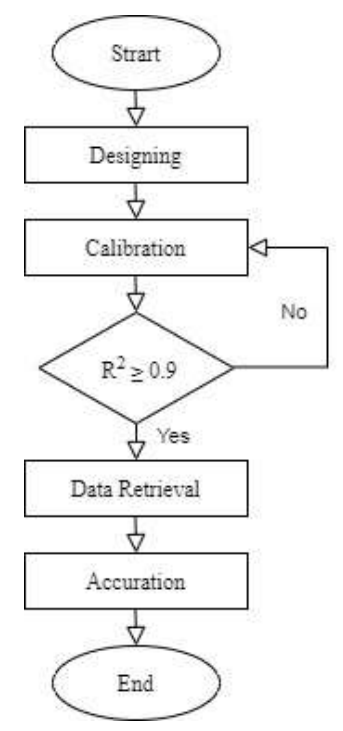

Figure 1 Research process flowchart.

The first stage is the design of the tool with the device design scheme shown in Figure 2. The telemedicine research process of cholesterol levels in the blood using a finger object as a detection of cholesterol disease using the DS-100A oximeter sensor is carried out by detecting the finger object contained in the sensor by utilizing absorption from the red LED and infrared. The power bank will provide voltage after the tool is turned on to all transmitter circuits. Then the data will be processed by the Arduino Uno microcontroller which will then send the data online using the blynk cloud as a data logger. Data from checking blood cholesterol levels is sent by the NodeMCU 8266 wifi module into Blynk Apps and can be accessed directly via Android and displayed on a 20x4 LCD. 


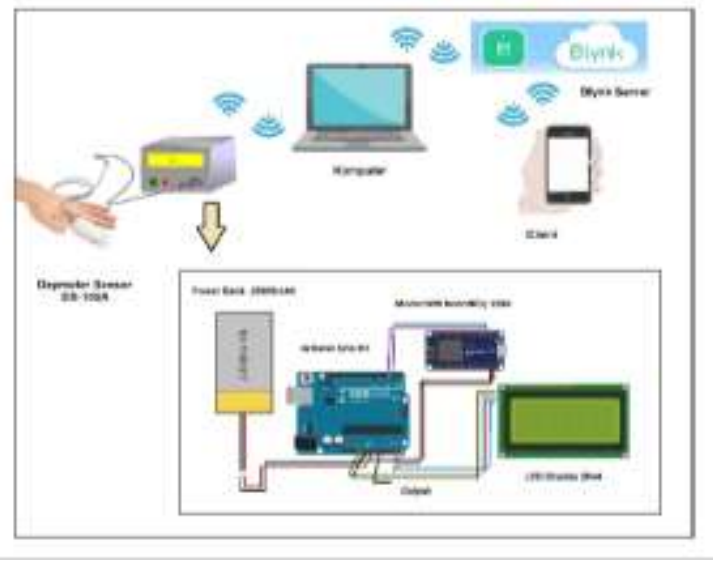

Figure 2 Tool design scheme.

The next stage is the calibration of the tool which is carried out to obtain a straight line equation $(y=a+$ bx) and the value of the coefficient of determination $\left(\mathrm{R}^{2}\right)$, where $y$ is the value of cholesterol levels measured using a standard measuring instrument Autocheck 3 in $1, x$ is the $\mathrm{ADC}$ value of non-invasive measuring instruments, $a$ and $\mathrm{b}$ are constants of the straight-line equation. The value of this linear tradeline is obtained from a simple linear regression between the $\mathrm{ADC}$ value and cholesterol levels. A straight-line equation was used to convert the ADC value into cholesterol levels and the coefficient of determination was used to determine the level of linear relationship between ADC values and blood cholesterol levels. If the value of the coefficient of determination is more than 0.9 , then the linear relationship between noninvasive measuring tools and standard measuring instruments is very accurate, so it can be continued to the stage of testing tools or data collection.

The next stage is testing the tool to determine the level of accuracy of the designed tool by comparing the measurement results from non-invasive measuring instruments and standard measuring instruments as comparison, namely Autocheck 3in 1 (mg/dl). In testing this tool, 35 randomly selected samples were used. The diagnostic results of samples with normal cholesterol levels to high cholesterol levels were taken from several community volunteers in Bojonegoro, East Java. The accuracy of the instrument is obtained by using the percentage of error of the non-invasive measuring instrument from equation (1)

$\%$ Error $=\frac{\text { Cholesterol data-Measurement data }}{\text { Cholesterol data }} \times 100 \%$

By using equation (1), the percentage value of the non-invasive measuring instrument will be obtained and then the value will be averaged. Furthermore, the accuracy of the tool can be calculated using equation (2).

Accuration $=100 \%-$ Average of (\%Error)

The telemedicine system for detecting cholesterol levels in the blood in this study utilizes serial communication between Arduino Uno and the NodeMCU 8266 wifi module as data processing and reading sensor data that will be sent by the wifi module to the server, then the results will be displayed on a 20x4 LCD and android screen via blynk apps. System testing is carried out by measuring 10 times to determine the speed of data transmission that can be carried out by the wifi module and the response of the blynk application in receiving data.

\section{RESULT AND DISCUSSION}

The results of making non-invasive tools are shown in Figure 3(a). The LCD displays ADC data (mV) in the form of R1 data or comes from the Red LED on the sensor and cholesterol levels in the blood $(\mathrm{mg} / \mathrm{dl})$. The prototype box measuring cholesterol levels is made using acrylic material measuring $16 \times 11 \times 6 \mathrm{~cm}$, there is a hole for a 20x4 MCD, Arduino Uno port, NodeMCU 8266 wifi module, switch button, and reset button. Furthermore, the data collection process is shown in Figure 3(b). The data collection procedure was carried out by first measuring the cholesterol level of the sample invasively using Autocheck 3in1, then followed by measuring the sample using a non-invasive tool. Measurements were carried out once on an invasive measuring instrument, while on a non-invasive measuring instrument repeated measurements were carried out 5 times on each sample to test the stability of a non-invasive instrument. Based on data analysis conducted on 35 repeated sample measurements, the stability of the non-invasive device reached $96.09 \%$. In each measurement, the stability of the instrument is achieved after an interval of \pm 6 seconds, so that when data collection, the index finger is held for a moment on the DS-100A finger oximeter sensor at that time.

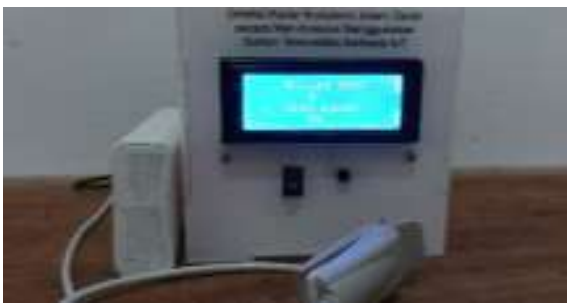

(a)

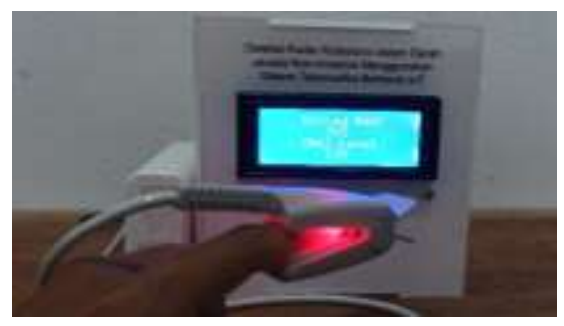

(b)

Figure 3 (a) Non-invasive cholesterol level measuring device (b) Data collection process. 


\subsection{Calibration}

Measurements using the Oxymeter Sensor produce ADC $(\mathrm{mV})$ values obtained from the index finger of each sample. This value is obtained from the network absorption properties of the red LED. The more concentrated the blood, the more infrared light will be absorbed so that only a little is caught by the photodiode. Vice versa, if the blood is getting thinner, more red light will pass through the tissue and be caught by the photodiode [19]. The results of the initial measurements for instrument calibration on 10 random sample volunteers are presented in the graph in Figure 4. This graph shows the relationship between the ADC value $(\mathrm{mV})$ from the results of non-invasive measuring instruments and cholesterol levels of samples from invasive measuring instruments Autocheck 3 in 1 .

Table 1. Percentage of Tool Error

\begin{tabular}{|c|c|c|c|}
\hline No. & $\begin{array}{c}\text { Invasive } \\
\text { Cholesterol } \\
(\mathrm{mg} / \mathrm{dl})\end{array}$ & $\begin{array}{c}\text { Non-invasive } \\
\text { Cholesterol } \\
(\mathrm{mg} / \mathrm{dl})\end{array}$ & Error (\%) \\
\hline 1. & 241 & 196.01 & 18.67 \\
\hline 2. & 225 & 261.09 & 16.04 \\
\hline 3. & 198 & 194.55 & 1.74 \\
\hline 4. & 183 & 204.05 & 11.50 \\
\hline 5. & 167 & 128.13 & 23.27 \\
\hline 6. & 234 & 154.57 & 33.94 \\
\hline 7. & 309 & 199.61 & 35.40 \\
\hline 8. & 143 & 150.38 & 5.16 \\
\hline 9. & 227 & 187.93 & 17.21 \\
\hline 10. & 207 & 181.80 & 12.17 \\
\hline 11. & 210 & 180.26 & 14.16 \\
\hline 12. & 173 & 161.39 & 6.71 \\
\hline 13. & 241 & 163.60 & 32.12 \\
\hline 14. & 184 & 181.53 & 1.34 \\
\hline 15. & 163 & 171.48 & 5.21 \\
\hline 16. & 113 & 148.42 & 31.35 \\
\hline 17. & 302 & 187.65 & 37.86 \\
\hline 18. & 215 & 215.55 & 0.26 \\
\hline 19. & 187 & 231.77 & 23.94 \\
\hline 20. & 147 & 165.71 & 12.73 \\
\hline 21. & 255 & 175.01 & 31.37 \\
\hline 22. & 184 & 220.54 & 19.86 \\
\hline 23. & 154 & 176.54 & 14.64 \\
\hline 24. & 155 & 176.84 & 14.09 \\
\hline 25. & 237 & 194.47 & 17.94 \\
\hline 26. & 194 & 165.93 & 14.47 \\
\hline 27. & 138 & 192.24 & 39.31 \\
\hline 28. & 139 & 193.78 & 39.41 \\
\hline 29. & 222 & 226.99 & 2.25 \\
\hline 30. & 258 & 264.06 & 2.35 \\
\hline 31. & 234 & 258.24 & 10.36 \\
\hline 32. & 192 & 157.08 & 18.19 \\
\hline 33. & 250 & 237.16 & 5.14 \\
\hline 34. & 211 & 214.04 & 1.44 \\
\hline 35. & 147 & 193.88 & 31.89 \\
\hline \multicolumn{3}{|c|}{ Average Error Persentage (\%) } & 17.24 \\
\hline \multicolumn{3}{|c|}{ Accuracy (\%) } & 82.76 \\
\hline
\end{tabular}

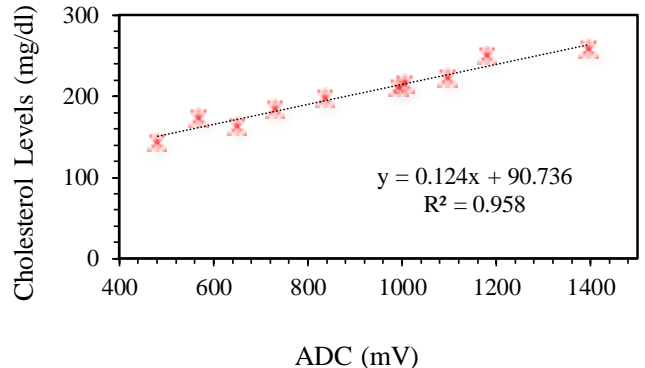

Figure 4 Simple linear regression graph of ADC measurement results and cholesterol levels for instrument calibration

The graph is plotted using simple linear regression so that the equation of the line is $\mathrm{y}=0.124 \mathrm{x}+90.736$ and the coefficient of determination $R^{2}=0.958$. The value of the coefficient of determination in simple linear regression ranges from $0 \leq R^{2} \leq 1$. Based on the value of the coefficient of determination obtained, the linear relationship between the ADC value of non-invasive devices and cholesterol levels of samples with standard invasive devices is very strong $\left(0 \leq \mathrm{R}^{2} \leq 8\right)$ [20]. Therefore, this tool can be tested at a later stage to get the accuracy value of the tool when compared to standard tools.

\subsection{Tool-testing}

Equipment testing was carried out by comparing noninvasive devices and standard invasive devices on 35 sample volunteers who were healthy and had. On the index finger of the left hand, AC and DC voltages are measured for each wavelength, where the red signal is denoted by $\mathrm{R}_{640}$ or $\mathrm{R} 1$ and the infrared signal is denoted by $\mathrm{R}_{960}$ or R2. Measurement of cholesterol levels in this study only used R1 data because the wavelength value of the red LED corresponds to the maximum absorption wavelength of cholesterol, which is $600-650 \mathrm{~nm}$ [21]. The absorbance level of $\mathrm{R} 1$ is directly proportional to the value of cholesterol levels, meaning that the higher the absorbance of R1 the value of the measured cholesterol level in the blood will be greater, on the contrary if the absorbance of R1 is low, the value of the measured cholesterol level will be low as well. This absorbance mechanism proves that the transmission intensity is directly proportional to the total concentration of the substance according to the Beer-Lambert law which is shown by equation (3).

$\mathrm{I}(\lambda)=\mathrm{I}_{0}(\lambda) \exp (-\mathrm{kcd})$

where $\mathrm{c}$ is the solute concentration and $\mathrm{d}$ is the thickness of the medium [22].

The performance of non-invasive cholesterol measuring instruments is evaluated by comparing the results of measurements from non-invasive measuring instruments and standard invasive measuring instruments in order to get the percentage of error. In order to achieve maximum cholesterol level measurement results, the 
subject should not perform strenuous physical activity for at least 15 minutes before the measurement begins [23]. During the measurement process, the subject is ensured to be at rest. Table 1 shows the measurement results to determine the percentage of non-invasive tool errors.

The performance accuracy of the designed device is $82.76 \%$. Non-invasive measuring instruments with an accuracy value of less than $95 \%$ cannot be said to be accurate [24], In addition, the accuracy of this tool does not meet the standards of medical instruments that can be used for humans with a value of $\geqslant 95 \%$ [25]. The final result of the error rate analysis shows that the predicted cholesterol level has not shown significant accuracy to diagnose medical actions on patients, but can be realized as a non-invasive determinant of the rough estimation of high and low cholesterol levels. The factors that cause the instrument's accuracy level does not meet the standard, namely the nature of the pulsatile signal that affects unstable arteries at any time which has implications for the Arduino Uno board signal reading to be unstable. The unstable pulsatile nature is also influenced by the uncontrolled sample state during the measurement process [22]. In addition, correction is an important factor to get better measurement results [26]. The accuracy of the tool can be increased by providing a correction to the algorithm and or adding a stabilizer for the input voltage of the oximeter sensor power supply [1].

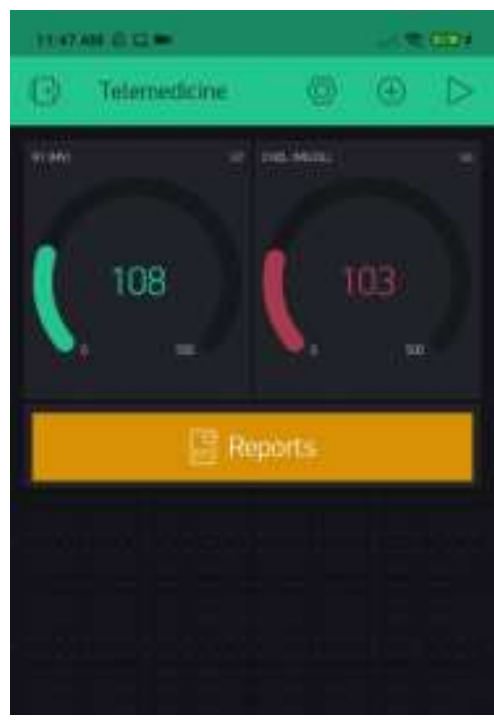

Figure 5 Blynk Application User Interface (UI) Display

The Telemedicine system response test was carried out in 10 trials following the time NodeMCU 8266 received and forwarded commands. The wifi network or access point used in the NodeMCU 8266 wifi module is a private wifi network from the Indosat provider with a PING (Packet Internet Gropher) value of $44 \mathrm{~ms}$. The results of testing the responsiveness of blynk apps to sending data by the wifi module from receiving data to reading values require varying time with the highest time being 2.97 seconds and the lowest time being 1.38 seconds with an average time required of 2.36 seconds. The delay that occurs is caused by an internet connection with a long PING too. The display of the blynk application is shown in Figure 5.

\section{CONCLUSION}

The development of a telemedicine system for the non-invasive detection of cholesterol levels has been successfully carried out by utilizing the DS-100A Oxymeter sensor based on the blynk application. Tool testing was carried out on 35 samples by comparing noninvasive measuring instruments and standard invasive measuring instruments (Autocheck 3in1). The results showed that the accuracy of the non-invasive blood cholesterol measuring device was $82.76 \%$. These results show great potential in determining the estimated value of cholesterol levels in the blood. Accuracy can be improved by providing corrections to the algorithm and or adding an input voltage stabilizer circuit to the prototype tool. The telemedicine system can display data that appears on the LCD screen to the Blynk application with an average data transfer time of $2.36 \mathrm{~s}$

\section{ACKNOWLEDGMENTS}

This research was supported by financial assistance from DIPA BOPTN LP2M 2021, Universitas Islam Negeri Walisongo Semarang, and Dr. Hamdan Hadi Kusuma, M.Sc. as a reviewer. We would like to thank all those who have helped to make this research a success.

\section{REFERENCES}

[1] I. Marhaendrajaya, E. Hidayanto, and Z. Arifin, "Desain dan Realisasi Alat Pengukur Kandungan Kolesterol dalam Darah Non- Invasive," Youngster Phys. J., vol. 6, no. 3, pp. 290-295, 2017.

[2] N. Oktariadi, "Sistem Telemedika Berbasis ICT untuk Pengukuran Kadar Kolesterol dalam Darah dengan Metode Non-Invasive,’ Univ. Mercu Buana, pp. 1-9, 2017.

[3] M. A. Malik, M. M. Yanti, and H. M. K. Stefana, “ Gambaran Kadar Kolesterol Total Darah pada Mahasiswa Fakultas Kedokteran Universitas Sam Ratulangi dengan Indeks Massa Tubuh $\geqslant 23$ Kg/m2,” J. e-Biomedik, vol. 1, no. 2, pp. 1008 1013, 2018, doi: 10.35790/ebm.6.2.2018.22174.

[4] E. Puspitasari, "Analisis Beberapa Faktor Risiko Hiperkolesterolemia pada Calon Jemaah Haji Berdasarkan SISKOHATKES Tahap 2 Tahap di Kabupaten Magetan," Skripsi Stikes Bhakti Husada Mulia Madiun, p. 121, 2018.

[5] R. R. Fitri, "Hubungan Asupan Lemak, Kadar Kolesterol dan Status Gizi dengan Kadar Kolesterol Pasien Hiperkolesterolemia Rawat Jalan di RSUD Dr. Moewardi Surakarta," Institut Teknologi Sains 
dan Kesehatan PKU Muhammadiyah Surakarta, 2019.

[6] P. Narkhede, S. Dhalwar, and B. Karthikeyan, "NIR Based Non-Invasive Blood Glucose Measurement," Indian J. Sci. Technol., vol. 9, no. 41, pp. 1-7, 2016, doi: 10.17485/ijst/2016/v9i41/98996.

[7] R. A. Buda and M. M. A. Ieee-embs, "A Portable Non-Invasive Blood Glucose Monitoring Device," IEEE Conf. Biomed. Eng. Sci., no. December, pp. 964-969, 2014.

[8] E. Y. Fitri and M. Karina, "Uji Analisis Alat Ukur Non-Invasive Real Time Kadar Kolesterol Darah," Semin. Nas. Keperawatan"Pemenuhan Kebutuhan Dasar dalam Perawatan Paliat. pada Era Norm. Baru", pp. 1-7, 2020.

[9] E. Satria and W. -, "Rancang Bangun Alat Ukur Kadar Gula Darah Non-Invasive Berbasis Mikrokontroler AT89S51 Dengan Mengukur Tingkat Kekeruhan Spesimen Urine Menggunakan Sensor Fotodioda," J. Fis. Unand, vol. 2, no. 1, pp. 40-47, 2013.

[10] D. R. Prasetyo, "Rancang Bangun Telemedicine Pengukur Kadar Kolesterol dalam Darah Berbasis Internet of Things," Universitas Semarang, 2019.

[11] V. L. D. S. N. Button, Principles of Measurement and Transduction of Biomedical Variables. Brazil: Department of Biomedical Engineering, School of Electrical and Computing Engineering, University of Campinas, São Paulo, Brazil, 2015.

[12] F. Ughi, "Proof-of-Concept Simulasi Kadar Saturasi Oksigen untuk Evaluasi Pulse Oximeter," ELKOMIKA J. Tek. Energi Elektr. Tek. Telekomun. Tek. Elektron., vol. 6, no. 1, p. 110, 2018, doi: 10.26760/elkomika.v6i1.110.

[13] G. Hariyanto, R. K. Welina, and C. S. A. Franky, "Rancang Bangun Okximeter Digital Berbasis Mikrokontroler ATMega16," J. Fis. dan Ter., vol. 1, no. 1, pp. 1-14, 2013, [Online]. Available: https://pubs.acs.org/doi/10.1021/acsami.9b03822.

[14] P. Kyriacou, K. Budidha, and T. Y. Abay, Optical Techniques for Blood and Tissue Oxygenation, vol. 1-3. Elsevier, 2019.

[15] S. Anagha and A. Suyampulingam, "A Better Digital Filtering Technique for Estimating of SPO2 and Heart Rate from PPG Signals," Proc. Int. Conf. Inven. Res. Comput. Appl. ICIRCA 2018, no. Icirca, pp. 804-809, 2018.

[16] V. P. Rachim and W. Y. Chung, "Wearable-band type Visible-Near infrared (VIS-IR) optical sensor for Non-Invasive Blood Glucose Monitoring," International Meet. Chem. Sensors-MCS 2018, pp. 73-74, 2018, doi: 10.1373/49.6.924.

[17] B. Gayathri, K. Sruthi, and K. A. U. Menon, "NonInvasive Blood Glucose Monitoring Using Near Infrared Spectroscopy," Int. Conf. Commun. Signal Process., pp. 1139-1142, 2017.

[18] Sugiyono, Penelitian Pendidikan Pendekatan Kuantitatif, Kualitatif, dan R\&D. Alfabet, 2010.

[19] M. Elgendi, PPG Signal Analysis An Introduction Using MATLAB, First Edit., vol. 53, no. 9. India: CRC Press, 2021.

[20] R. E. Ndruru, M. Situmorang, and G. Tarigan, "Analisa Faktor-Faktor Yang Mempengaruhi Hasil Produksi Padi di Deli Serdang," Saintia Mat., vol. 2, no. 1, pp. 71-83, 2014.

[21] S. Mukherjee, H. Raghuraman, and A. Chattopadhyay, "Membrane Localization and Dynamics of Nile Red: Effect of Cholesterol," Biochim. Biophys. Acta - Biomembr., vol. 1768, no. 1, pp. 59-66, 2007, doi: 10.1016/j.bbamem.2006.07.010.

[22] L. Umar, I. Firmansyah, and R. N. Setiadi, "Design of Pulse Oximetry Based on Photoplethysmography and Beat Rate Signal Using DS-100 Probe Sensor for SpO2 Measurement," ISSIMM 2018 - 3rd Int. Semin. Sensors, Instrumentation, Meas. Metrol. Proceeding, vol. 0, no. 2, pp. 44-47, 2018, doi: 10.1109/ISSIMM.2018.8727725.

[23] L. Agustine, G. Albert, M. Ivan, and dkk, Heart Rate Monitoring Device for Arrhythmia Using Pulse Oximeter Sensor Based on Android. Surabaya: Irfansyah, A.N. dan Ahmad, Z., 2018.

[24] M. Sulehu and A. H. Senrimang, "Program Aplikasi Alat Pengukur Kadar Glukosa Dalam Darah Non Invasive Bebasis Desktop," Inspir. J. Teknol. Inf. dan Komun., vol. 8, no. 1, pp. 16-24, 2018, doi: 10.35585/inspir.v8i2.2454

[25] H. Suyono and Hambali, "Perancangan Alat Pengukur Kadar Gula dalam Darah Menggunakan Teknik Non-Invasive Berbasis Mikrokontroler Arduino Uno," JTEV (Jurnal Tek. Elektro dan Vokasional), vol. 06, no. 01, pp. 69-76, 2020.

[26] R. Ekawita, A. A. Nasution, E. Yuliza, N. Suardi, and S. Suwarsono, "Development of Non-Invasive Blood Glucose Level Monitoring System using Phone as a Patient Data Storage," J. Penelit. Fis. dan Apl., vol. 10, no. 2, p. 103, 2020, doi: 10.26740/jpfa.v10n2.p103-113 